\title{
Diagnostic efficiency of an ultrarapid endoscopy room test for Helicobacter pylori
}

\author{
A V Thillainayagam, A S Arvind, R S Cook, I G Harrison, S Tabaqchali, M J G Farthing
}

\begin{abstract}
There are several reliable methods for detecting Helicobacter pylori but all have as a major disadvantage the time required to yield a definitive result. We have modified the standard urease test so that a positive result is available in one minute. We describe the use of this test in biopsy specimens from the gastric antrum from 220 consecutive patients referred for upper gastrointestinal endoscopy. The performance of the 'one iminute test' was compared with a standard urease test, Gram stain, and microbiological culture. Using culture as the 'gold standard' $80(36 \%)$ of the patients were $H$ pylori positive. The one minute test produced no false positives and showed a sensitivity of $89 \%$ and specificity of $100 \%$, while the predictive values of a positive and negative test were $100 \%$ anbd $94 \%$ respectively. The diagnostic efficiency of the test was $96 \%$ compared to $85 \%$ for both the Gram stain and direct urease test. All positive results using the one minute test were available within one minute. The test is easy to prepare and costs approximately $£ 0.04$. This new modification of the urease test should be superior to the currently available urease tests because a reliable result will be available in almost $90 \%$ of infected individuals even before endoscopy is completed.
\end{abstract}

A variety of methods have been developed for the detection of Helicobacter pylori in gastric mucosa. ${ }^{1}$ Non-invasive methods currently available are serodiagnosis and a breath test using isotopically labelled urea, but these are not yet in widespread clinical use. Although of high sensitivity, specificity, and predictive value, the breath tests ${ }^{2-5}$ may be limited by expense and, when $\left[{ }^{14} \mathrm{C}\right]$-urea is used, radiation exposure. Serological assays have been hindered by a relatively high number of false negatives and false positives, ${ }^{6}$ although two new enzyme linked immunosorbent assays (ELISA) seem to have improved precision. ${ }^{78}$ These non-invasive methods will probably prove useful in unravelling the natural history of $H$ pylori infection, and may come to play a part in posttreatment surveillance programmes. For many, though, they are not available in daily clinical practice.

Several approaches to diagnosis using gastric (usually antral) biopsy specimens have been described but they all have a major disadvantage in common which is the time required to get a definitive result. Histological examination of biopsy sections using a variety of stains ${ }^{9-16}$ has been shown to be quicker and simpler than the Warthin-Starry silver stain used by Warren and Marshall, ${ }^{17-20}$ but at best the results will not be available from several hours to two to three days after endoscopy..$^{21}$ Histological methods seem to have a lower specificity than culture because of the possible presence of other spiral and Campylobacter like organisms which can be found in the human stomach. ${ }^{22}{ }^{23}$ Two recent immunohistological innovations seem to be capable of yielding results in under two hours ${ }^{24} 25$ but neither as yet has been applied outside the research laboratory. The other diagnostic 'gold standard' apart from the histological demonstration of $H$ pylori in biopsy specimens is culture of the organism, but this can take three to six days for the results to be known. ${ }^{21}$

An unusual characteristic of $H$ pylori is rapid urea hydrolysis due to the presence of large amounts of preformed urease in the organisms. The first description of this phenomenon by Langenberg et $a l^{26}$ was soon followed by its application to the diagnosis of $\mathrm{H}$ pylori in biopsy specimens. ${ }^{27}$ Christensen's 2\% urea broth was used as enzyme substrate and ammonia production detected by the colour change induced in a $\mathrm{pH}$ indicator. In this initial study only $50 \%$ of biopsy specimens containing $H$ pylor $i$ were positive by six hours, some requiring up to 24 hours to yield a positive result. Since then many modified versions of the biopsy urease test have been described, in an attempt to increase speed and reliability. ${ }^{28-33}$ But, with even the best of these, at least 20 minutes is required for a definite positive result.

We have used preformed urease in $H$ pylori to detect the organism in gastric biopsy specimens but found that changing the incubation conditions permitted ultrarapid diagnosis, the results of which are available in the endoscopy room even before the instrument is removed from the patient. ${ }^{34} \mathrm{We}$ have now extended these studies and compared the results of this rapid test with other standard techniques for detecting $H$ pylori.

\section{Methods}

Two antral biopsy specimens were taken from within $5 \mathrm{~cm}$ of the pylorus from 220 consecutive patients (110 men) referred for oesophagogastroduodenoscopy (Olympus GIF XQ10). The mean age of the patients was 56 years (range 19-94 years). This study was approved by the Ethical Committee of the City \& Hackney Health District.

MICROBIOLOGICAL CULTURE, GRAM STAIN, AND STANDARD UREASE TEST

One biopsy specimen was transported to the microbiology laboratory attached to the inside of a sterile bijou bottle containing approximately 
$0.5 \mathrm{ml}$ sterile saline. All specimens were processed within two hours of receipt. Using a sterile swab, the biopsy specimen was smeared on to a sterile glass slide for Gram staining and using the same swab the biopsy specimen was then smeared and inoculated onto a selective medium (Oxoid BAB No 2 containing Skirrow's formula for selective supplement) ensuring maximum contact..$^{35}$ The remainder of the biopsy was then placed into $0.5 \mathrm{ml}$ of Christensen's $2 \%$ urea broth at $37^{\circ} \mathrm{C} .{ }^{26}$ The culture plates were then incubated at $37^{\circ} \mathrm{C}$ under microaerophilic conditions using Campypak envelopes in Gas Pak jars (BBL Microbiology Systems, Becton Dickinson). The cultures were examined after four and seven days. Colonies were identified as $H$ pylori by their characteristic morphology on Gram stain, oxidase positivity, and strong production of urease.

\section{IN VITRO PRODUCTION OF UREASE}

One $H$ pylori strain isolated from an antral biopsy specimen was used to test urea production in vitro. Unbuffered solutions of urea in deionised water at a pH of 6.8 were prepared and to $0.5 \mathrm{ml}$ aliquots thereof were added one to two drops of a $1 \%$ phenol red (free acid) solution. Using a range of concentrations of $H$ pylori, we were able to show an almost immediate colour change from yellow to pink when $2 \times 10^{6}$ or more bacteria were added to a $0.5 \mathrm{ml}$ aliquot of urea solution. The colour change occurred instantaneously over a range of urea concentrations from $0.025-10 \%$ $(\mathbf{w} / \mathbf{v})$.

\section{ONE MINUTE UREASE TEST}

An antral mucosal biopsy specimen was placed immediately into a capped Eppendorf tube containing $0.5 \mathrm{ml}$ freshly prepared $10 \%$ urea $(\mathrm{w} / \mathrm{v})$ in deionised water at a pH of around 6.8 to which had been added two drops of $1 \%$ phenol red (free acid) as a $\mathrm{pH}$ indicator. A positive result was recorded if there was a colour change from yellow to pink within the first minute. Although the ideal $\mathrm{pH}$ for urease activity is $8 \cdot 2,{ }^{36}$ we have been unable to improve on the rapidity of the test by using other $\mathrm{pH}$ indicators such as $\mathrm{m}$-cresol $(\mathrm{pH}$ range $7 \cdot 4-9 \cdot 0)$ and thymol blue ( $\mathrm{pH}$ range $8 \cdot 0$ 9.6).

\section{STATISTICAL ANALYSIS}

The results were compared using the "comparison of proportions from many samples' method. ${ }^{37}$

\section{Results}

Microbiological culture grew $H$ pylori from 80 (36\%) of the 220 patients. These patients are representative of the workload of most endoscopy units, with $H$ pylori being present more commonly in patients over the age of 45 years (Table I) and closely associated with peptic ulcers.

The 'one minute test' correctly identified 71 of the $80 \mathrm{H}$ pylori positive specimens and there were no false positives (Table II). Gram stain detected 66 of the 80 positive specimens but there were 10 false positive results as well as a greater number of false negatives. The conventional urease test also performed less reliably than the one minute test. Although there were 86 positive results, 20 were false positives, due almost certainly to the presence of other urease producing bacteria. ${ }^{38}$ In addition, there were 13 false negatives. The one minute test had a comparable sensitivity to the conventional urease test $(89 \% v 83 \%)$ but had a greater specificity $(100 \% \vee 86 \% ; \mathrm{p}<0.001)$. This makes the predictive value of a positive one minute test $100 \%$ and that of a negative test $94 \%$ - that is, greater than both the Gram stain and the conventional urease test $(\mathrm{p}<0.05)$. The diagnostic efficiency of the one minute test was also significantly greater than the others $(p<0.001)$. The major clinical advantage of the one minute test was that the result was available immediately, whereas Gram stain took 1-3 hours, conventional direct urease test up to 24 hours, and culture four to seven days.

\section{Discussion}

As many patients with dyspepsia are investigated by endoscopy it seemed appropriate to develop a rapid diagnostic test for $H$ pylori, the results of which would be available in the endoscopy room immediately after the examination. We have made relatively minor changes to the well established urease test for $H$ pylori but now have a diagnostic approach that yields a positive result in almost $90 \%$ of infected patients within one minute of retrieving the specimen. All other invasive and non-invasive methods for detecting $H$ pylori take considerably longer and thus may not be available to the clinician during the endoscopy consultation (Table III). We think the main reason our modification produces more rapid results is that the urea in water solution, unlike Christensen's urea broth, is unbuffered. Thus any changes in $\mathrm{pH}$ will be detected quickly through their effect on the $\mathrm{pH}$ indicator. Our modification also has the advantage that, unlike

TABLE I Details of patients' age and $\mathrm{H}$ pylori status

\begin{tabular}{lll}
\hline & \multicolumn{2}{l}{ H pylori status } \\
\cline { 2 - 3 } Age (years) & \multicolumn{3}{l}{ Positive: $N o(\%)$} & $\begin{array}{l}\text { Negative: } \text { No } \\
(\%)\end{array}$ \\
\hline Men & & \\
$<45$ & $8(26)$ & $23(74)$ \\
$>45$ & $35(44)$ & $44(56)$ \\
Women & $10(33)$ & $20(67)$ \\
$<45$ & $27(34)$ & $53(66)$ \\
$>45$ & $80(36)$ & $140(64)$ \\
Total & & \\
\hline
\end{tabular}

TABLE II Comparative efficiency of diagnostic tests for H pylori

\begin{tabular}{lcccc}
\hline Test & Culture & $\begin{array}{l}\text { One } \\
\text { minute }\end{array}$ & $\begin{array}{l}\text { Gram } \\
\text { stain }\end{array}$ & $\begin{array}{c}\text { Direct } \\
\text { urease }\end{array}$ \\
\hline Positive & 80 & 71 & 66 & 86 \\
Negative & 140 & 149 & 154 & 134 \\
False positive & - & 0 & 10 & 20 \\
False negative & - & 9 & 23 & 13 \\
Sensitivity (\%) & - & $89 \star$ & 70 & 83 \\
Specificity (\%) & - & $100 \$$ & 94 & 86 \\
$\begin{array}{l}\text { Positive (\%) } \\
\text { predictive value }\end{array}$ & - & $100+\S$ & 85 & 77 \\
$\begin{array}{l}\text { Negative (\%) } \\
\text { predictive value }\end{array}$ & - & $94 \ddagger$ & 85 & 90 \\
$\begin{array}{l}\text { Efficiency (\%) } \\
\text { Ond }\end{array}$ & - & $96+\S$ & 85 & 85
\end{tabular}

One minute $v$ Gram stain ${ }^{\star} \mathrm{p}<0.01 ; \uparrow \mathrm{p}<0.001 ; \neq \mathrm{p}<0.05$; one One minute $v$ Gram stain $* \mathrm{p}<0.01$
minute $v$ direct urease $\$ \mathrm{p}<0.001$ 
TABLE III Comparative speeds of other available diagnostic tests for $\mathrm{H}$ pylori

\begin{tabular}{|c|c|}
\hline Method (and reference) & Time to positive result \\
\hline $\begin{array}{l}\text { CLO test } t^{28}{ }^{29} \\
\text { Microtitre biopsy urease test }{ }^{31} \\
4 \text { Hour rapid urease test }{ }^{32} \\
6 \% \text { Rapid urease test } t^{33} \\
\text { Modified biopsy urease test } t^{33} \\
\text { Enzyme linked immunosorbent } \\
\text { assay }{ }^{60-12}\end{array}$ & $\begin{array}{l}20 \min -24 h \\
1-24 h \\
2-4 h \\
20 \text { min }-2 h \\
1-24 h \\
4-6 h\end{array}$ \\
\hline $\begin{array}{l}\text { Immunostaining:s } \\
{ }^{14} \mathrm{C} \text {-urea breath test }{ }^{2-5} \\
{ }^{13} \mathrm{C} \text {-urea breath test }{ }^{2}\end{array}$ & $\begin{array}{l}\text { Approx } 2 \mathrm{~h} \\
>30 \mathrm{~min} \\
>60 \mathrm{~min}\end{array}$ \\
\hline
\end{tabular}

the conventional urease test, there were no false positives. Other bacteria also produce urease, albeit in much smaller quantities, ${ }^{3638}$ but under prolonged incubation in the conventional urea broth this seems to be sufficient to effect a colour change. The one minute test will miss approximately $10 \%$ of $H$ pylori positive patients and one can therefore make a strong argument for back up microbiological culture or histology. Gastritis and $H$ pylori colonisation can be patchy, although usually in body type mucosa rather than in the antrum. ${ }^{39}$ Taking two antral biopsy specimens may therefore reduce sampling error considerably and improve even further the sensitivity of the one minute test.

The test solutions are easy to prepare even for a gastroenterologist, and a single test costs less

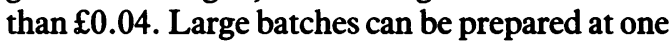
time but should be stored in a freezer and only thawed before use (unpublished observations).

Thus the one minute test has practical advantages for clinical gastroenterologists who require a rapid, accurate, sensitive, and specific method of diagnosing $H$ pylori infection in patients with dyspepsia. In more than $\mathbf{9 0 \%}$ of infected patients the presence of $H$ pylori can be detected in the endoscopy room even before the instrument is withdrawn. This may help in planning therapeutic strategies, lead where appropriate to prompt introduction of treatment, and possibly reduce recall outpatient appointments.

MJGF is a Wellcome Trust Senior Lecturer and gratefully acknowledges the financial support of the Wellcome Trust. We are indebted to Ms Nicola Herrera for her secretarial assistance.

1 Megraud F. Comparison of different tests for Campylobacter pylori. Scand f Gastroenterol 1988; 23 (Suppl 142): 64-8.

2 Graham DY, Klein PD, Evans DJ Jr, et al. Campylobacter pylori detected noninvasively by the ${ }^{13} \mathrm{C}$-urea breath test. Lancet 1987; i: 1174-7.

3 Bell GD, Weil J, Harrison G, et al. ${ }^{14} \mathrm{C}$-urea breath analysis, a non-invasive test for Campylobacter pylori in the stomach. Lancet 1987; i: 1367-8.

4 Marshall BJ, Surveyor I. Carbon-14 urea breath test for the diagnosis of Campylobacter pylori asssociated gastritis. F Nucl diagnosis of Campylo 1988 ; 29: $11-6$.

5 Rauws EAJ, Royen EAV, Langenberg W, Woensel JV, Vrii AA, Tytgat GN. ${ }^{4} \mathrm{C}$-urea breath test in $C$ pylori gastritis. Gut 1989; 30: 798-803.

6 Goodwin CS, Blincow E, Peterson G, et al. Enzyme-linked immunosorbent assay for Campylobacter pyloridis: correlation with presence of $C$ pyloridis in the gastric mucosa f Infect Dis 1987; 155: 488-94.

7 Evans DJ Jr, Evans DG, Graham DY, Klein PD. A sensitive and specific serological test for detection of Campylobacter pylori infection. Gastroenterology 1989; 96: 1004-8.

8 Dent JC, McNulty CAM, Uff JS, Gear MWL, Wilkinson SP. Campylobacter urease: a new serological test. Lancet 1988; i 1002 .

9 Zarate JO, Lucero RS, Espiniella F, Padorno L, Apud A Localization of piloricus Campylobacter and its relation with quantity and type of gastritis. Histological staining variants. quantity and type of gastritis.

10 Trowell JE, Yoong AKH, Saul KJ, Gant PW, Bell GD. Simple half-Gram stain for showing the presence of Campylobacter pyloridis in sections. $\mathcal{F}$ Clin Pathol 1987; 40: 702.
11 Westblom TU, Madan E, Kemp J, Subik MA, Tseng J. Improved visualisation of mucus penetration by Campylobacter pylori using a Brown-Hopps stain. F Clin Pathol 1988; 41: 232.

12 Gray SF, Wyatt JI, Rathbone BJ. Simplified techniques for identifying Campylobacter pyloridis. F Clin Pathol 1986; 39 1280

13 McMullen L, Walker MM, Bain LA, Karim QN, Baron JH. Histological identification of Campylobacter using Gimenez technique in gastric antral mucosa. $\mathcal{F}$ Clin Pathol 1987; 4 464-5

14 Walters LL, Budin RE, Paull G. Acridine orange to identify Campylobacter pyloridis in formalin fixed paraffin-embedded gastric biopsies. Lancet 1986; i: 42.

15 Burnett RA, Brown IL, Findlay J. Cresyl fast violet staining method for campylobacter like organisms. F Clin Pathol 1987; 40: 353.

16 Peterson WL, Lee E, Feldman M. Relationship between Campylobacter pylori and gastritis in healthy humans after administration of placebo or indomethacin. Gastroenterology 1988; 95: 1185-97.

17 Warren JR. Unidentified curved bacilli on gastric epithelium in active chronic gastritis. Lancet 1983; i: 1273.

18 Marshall B. Unidentified curved bacilli on gastric epithelium in active chronic gastritis. Lancet 1983; i: 1273-5.

19 Marshall BJ, Warren JR. Unidentified curved bacilli in the stomach of patients with gastritis and peptic ulceration. Lancet 1984; i: $1311-5$.

20 Marshall BJ, Royce H, Annear DI, et al. Original isolation of Campylobacter pyloridis from human gastric mucosa. Microbios Lett 1984; 25: 83-8.

21 Marshall BJ, McGechie BD, Rogers PA, Glancey RJ, Pyloric Campylobacter infection and gastroduodenal disease. Med $\mathcal{F}$ Aust 1985; 142: 439-44.

22 Kasper G, Dickgiesser N. Isolation from gastric epithelium of Campylobacter-like bacteria that are distinct from 'Campylobacter pyloridis'. Lancet 1985; i: 111-2.

23 Dent JC, McNulty CAM, Uff JC, Wilkinson SP, Gear MWL. Spiral organisms in the gastric antrum (abstr). Lancet 1987; ii: 96.

24 Engstrand L, Pahlson C, Schwan A, Gustavsson S. Monoclonal antibodies for detection of Campylobacter pylori in
biopsy smears and frozen section. Scand $\mathcal{f}$ Gastroenterol 1988; 23 [Suppl 142]: $50-2$.

25 Negrini R, Lisato L, Cavazzini L, ct al. Monoclonal antibodies for specific immunoperoxidase detection of Campylobacter pylori. Gastroenterology 1989; 96: 414-20.

26 Langenberg ML, Tytgat GN, Schipper MEI, Rietra PJGM, Zanen HC. Campylobacter-like organisms in the stomach of patients and healthy individuals. Lancet 1984; i: 1348.

27 McNulty CAM, Wise R. Rapid diagnosis of Campylobacterassociated gastritis. Lancet 1985; i: 1443-4.

28 Morris A, McIntyre D, Rose T, Nicholson G. Rapid diagnosis of Campylobacter pyloridis infection. Lancet 1986; i: 149.

29 Marshall BJ, Warren JR, Francis GJ, Langton SR, Goodwin CS, Blincow ED. Rapid urease test in the management of Campylobacter pyloridis-associated gastritis. Am $\mathcal{F}$ Gastroenterol 1987; 82: 200-10.

30 Das SS, Bain LA, Karim QN, Coelho LG, Baron JH. Rapid diagnosis of Campylobacter pyloridis infection. $\mathcal{F}$ Clin Pathol 1987; 40: 701-2.

31 Hazell SL, Borody TJ, Gal A, Lee A. Campylobacter pyloridis gastritis. I. Detection of urease as a marker of bacterial colonisation and gastritis. Am $\mathcal{f}$ Gastroenterol 1987; 82: 292-6.

32 Vaira D, Holton J, Cairns S, Falzon M, Salmon P. Four hour rapid urease test (RUT) for detecting Campylobacter pylori: is it reliable enough to start treatment? $\mathcal{F}$ Clin Pathol 1988; 41 355-6.

33 Vaira D, Holton J, Cairns S, et al. Urease tests for Campylo bacter pylori: care in interpretation. $\mathcal{F}$ Clin Pathol 1988; 41 : 812-3.

34 Arvind AS, Cook RS, Tabaqchali S, Farthing MJG. One minute endoscopy room test for Campylobacter pylori. Lance 1988; i: 704.

35 Skirrow MB. Campylobacter enteritis: a 'new' disease. B $M \mathcal{F}$ 1977; ii: 9-11.

36 Mobley HLT, Cortesia MJ, Rosenthal LE, Jones BD. Characterization of urease from Campylobacter pylori. $\mathcal{f}$ Clin terization of urease from
Microbiol $1988 ; 26: 831-6$.

37 Fleiss JL. The comparison of proportions from many samples. In: Statistical methods for rates and proportions. Chichester: Wiley, 1973: 92-108.

38 Raisanen $\mathrm{S}$, Sodervik $\mathrm{H}$. Colonisation of gastric lesions by urease-positive bacteria. Am f Clin Path 1988; 90: 749

39 Wyatt JI, Primrose J, Dixon MF. Distribution of Campylobacter pylori in gastric biopsies. 7 Pathol 1988; 155: 350A.

40 Kaldor J, Tee W, McCarthy P, Watson J, Dwyer B. Immune response to Campylobacter pylori in patients with peptic ulceration. Lancet 1985; i: 921.

41 Rathbone BJ, Wyatt JI, Worsley BW, et al. Systemic and local antibody responses to gastric Campylobacter pylori in nonulcer dyspepsia. Gut 1986; $27: 642-7$.

42 Booth L, Holdstock G, MacBride H, et al. Clinical importance of Campylobacter pyloridis and associated serum IgG and IgA of Campylobacter pyloridis and associated serum IgG and IgA
antibody responses in patients undergoing upper gastroinantibody responses in patients undergoing upper

43 McNulty CAM, Dent JC, Uff JS, Gear MWL, Wilkinson SP. Detection of Campylobacter pylori by the biopsy urease test: an assessment in 1445 patients. Gut 1989; 30: 1058-62. 